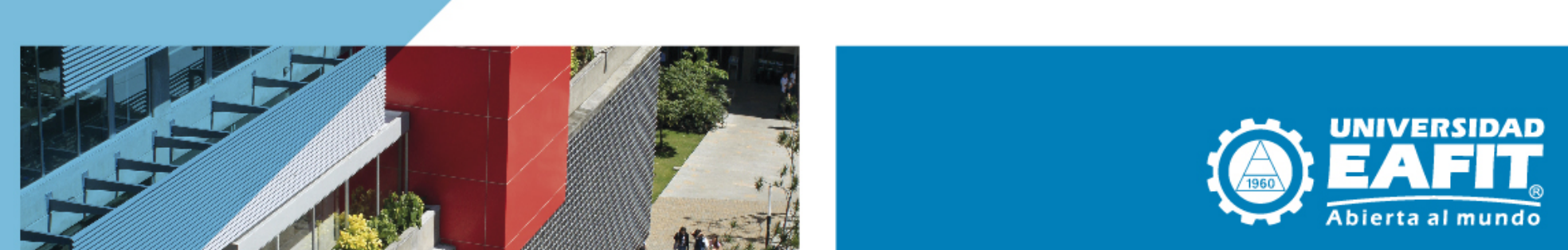

Escuela de Economía y Finanzas

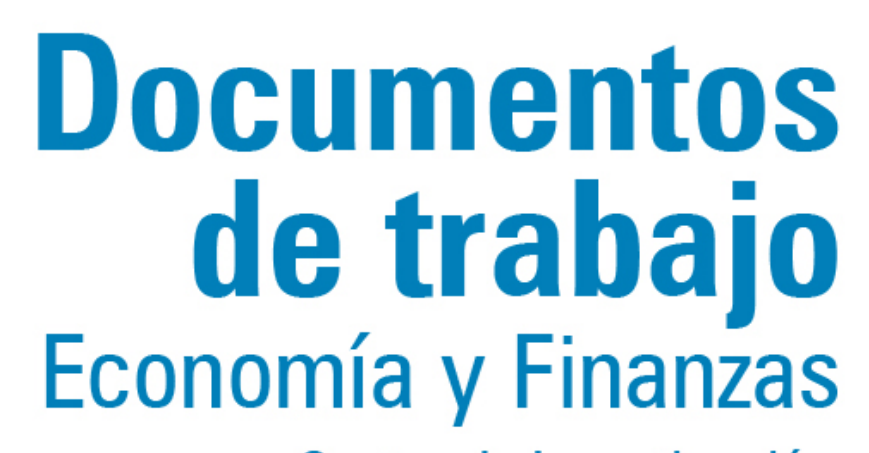

Centro de Investigación Económicas y Financieras

No. 14-22 Decisions about Postsecondary Education, 2014 their returns in Colombia 


\title{
Decisions about Postsecondary Education, their returns in Colombia
}

\author{
Monica Ospina Londoño \\ Universidad EAFIT, Medellín - Colombia \\ Fabiola Saavedra Caballero \\ Universidad EAFIT, Medellín - Colombia
}

(version: June $\left.4^{\text {th }}, 2014\right)$

\begin{abstract}
This study analyzes the economic returns to schooling decisions made by high school graduates in Colombia. We wanted to verify if the economic returns (wages) obtained by newly postsecondary education graduates compensate the economic and psychological investment they made in order to get that academic degree. To answer that question, we estimated these economic returns for each type of postsecondary degree available in Colombia (technical education, technological education, undergraduate studies, graduate studies) by origin of the institution (public or private). Our methodological strategy includes the generation of a micro-data base that contains agents' socio-economic background and also their individual labor market outcomes. Because agents with very similar characteristics and the same schooling decisions might get different economic returns from education, we considered as part of our empirical strategy the inclusion of an approximation of agents' cognitive abilities.
\end{abstract}

Key Words: postsecondary education, labor market outcomes

JEL CODE: I210, J24

Contact information: Fabiola Saavedra Caballero

Email: fsaavedr@eafit.edu.co ; fsaavedra.caballero@gmail.com

Universidad EAFIT, Medellín - Colombia

Address: Carrera 49 № 7 Sur - 50, Bloque 26, segundo piso (Escuela de Economía y Finanzas) 


\section{Introduction}

Essentially, postsecondary education demand is based on students' perception about their future economic returns. Nevertheless, these economic returns not only depend on the academic degree achieved, but also on aspects such as the characteristics of the institution where the student obtained that degree, the features of the program he chose and the student's inherent cognitive abilities. However, as Maxwell (1970) and Dolton and Vignoles (2000) show, to invest on postsecondary education does not guarantee economic returns that pay off the financial and psychological investment the student made.

As result of this uncertainty about the future economic returns, the education system might suffer a loss of efficiency. First, an excess of demand of education programs in specific knowledge areas can affect the costs of the programs, detriment the quality of them and also create a vicious circle affecting the expected economic returns. Second, any change of perception about the expected economic returns may increase desertion or extend the regular education cycle. Third, this uncertainty prevents policy makers to properly identify where to focus the funding and where to increase the education coverage. Finally, if there is no accuracy about the economic returns of postsecondary education, the investment made by the government is not optimal, hence, is not aligned with the productivity objectives of the country.

That's why, the relevance of estimating the economic returns to postsecondary education can be considered from different perspectives. From an individual one, it can tell if the investment a person makes in order to get that academic degree is compensated by a wage premium. From a labor market perspective, to estimate these economic returns will help validate if it's easier for an individual with a postsecondary educational level to get a better job (higher salary) than it would be had not had that academic degree. Finally, from a public policy perspective these estimations could help government to 
target the investment on education more efficiently by focusing on those academic degrees that bring higher economic returns to individuals, which means that make them more productive.

Colombia is a perfect scenario to study the economic returns to postsecondary education because of the availability of important information al individual level such as socio-economic characteristics, Saber11 test scores (standardized test) and recently graduate workers' salaries. Saber 11 is an academic performance test taken to senior year students in order to evaluate their academic competences and abilities developed through secondary education. About workers' salaries, the Employment Observatory for Education $\left(O L E^{1}\right)$ tracks recently postsecondary graduate students who work in the formal sector of the economy and gathers information about their salaries and places where they are working at, classified by economic activity.

Our methodology is focused on the estimation of the individual economic returns to each postsecondary education degree in Colombia by type of academic degree and origin of institution. Then we compared the returns obtain at university (bachelor degree) with each postsecondary education degree. Our objective is to answer: What would have happened to individuals that hold a bachelor degree as their higher educational level had they had a different post-secondary education degree? To accomplish our goal, we adapted Reyes et al. (2013) empirical strategy that proposes the inclusion of individuals' abilities while comparing the different scenarios of postsecondary education, and complemented it with quasiexperimental techniques.

Therefore, the main contribution of this investigation is to include the heterogeneity of the economic returns into the analysis; this because, agents with very similar characteristics and the same schooling decisions might get different economic returns. We attribute these differences to cognitive abilities (that

\footnotetext{
1 “Observatorio Laboral para la Educación” in spanish.
} 
also reflect somehow the individual's innate abilities such as student's intelligence, an educationsupportive environment, studying habits, motivation and discipline among others). Also, these characteristics influence the student while making his postsecondary schooling decision, even though, he might not be totally aware of them.

Our results ${ }^{2}$ show that, individuals that attended universities have around $7 \%$ higher salaries had they hold a technological degree. Nevertheless, their salaries are around 9\% below had they hold a professionaltechnical degree (programs for a particular career or job), $61 \%$ below had they hold a specialization and 84\% had they hold a Master's degree. These results show an important impact over individual's economic returns (wages) once proficiency on a specific field is developed.

This first part of the article gives an overview about our research. In section two we depict the Colombian postsecondary education system structure and its characteristics while in section three we present a review about the economic returns to postsecondary education. Section four encloses our model and empirical strategy; it also contains a description of our data and information sources. Section five describes the results of our estimations. Finally, in section six, we discuss the results and provide some conclusions.

\section{Postsecondary Education in Colombia}

As the Colombian Political Constitution of 1991 states, education is a right for Colombian people and also a public service that the government has to provide and supervise. That is why; the government has the responsibility to guarantee adequate coverage and also the minimal conditions for people to access and to stay at the education system.

\footnotetext{
${ }^{2}$ The estimation controls for individual's abilities, socioeconomic background, institution's characteristics and tuition costs among others (these covariates are detailed on Section 4)
} 
According to the Colombian Ministry of Education $\left(\mathrm{MEN}^{3}\right)$, the Colombian Education System has five different stages: Initial Education, Preschool, Basic Education, Medium Education and Higher Education (this last one known as Educación Superior). Basic Education includes five years of elemental education and four years of high school. The fourth stage called "Medium Education" includes junior and senior years and finalizes with the high school diploma. After receiving the high school diploma and taking a compulsory standardized test provided by the government (SABER-11) ${ }^{4}$, the student can access "Higher Education" that now on, we will call "Postsecondary Education" in order to harmonize this term with international standards.

There are two different levels of Postsecondary Education, undergraduate and graduate; and each one of them awards different degrees to their graduates. Undergraduate level includes Technical Level, Technological Level and Professional Level. About Graduate level, it includes Specialization, Master Degree and Doctoral Degree.

It is important to mention that Colombian Education System proposes propaedeutic cycles (each previous education level serves as basis for the next one) which means that students should begin postsecondary education at technical level, then advance until technological level, get a professional degree and then move to a graduate level (specialization then master's and finally doctorate) in order to gather knowledge and skills at different levels in the same knowledge area.

\footnotetext{
${ }^{3}$ In spanish "Ministerio de Educación Nacional"

${ }^{4}$ It is worth to mention that even though SABER 11 test is compulsory and should be used as reference to admit students in postsecondary education, some institutions of postsecondary education prefer to complement it with their own tests to admit students.
} 
Postsecondary education is provided by Institutions of Higher Education (IES ${ }^{5}$ ) and they can be classified by two different criteria. The first one, the academic criteria reflects the scope each IES has and the programs that can be taught at them. The second one is the origin of the institution, which means that the IES can be public or private. Table 1 summarizes which type of programs can be given according to the academic criteria of the IES.

There is also another type of institutions that offer some postsecondary education but that we are not including in our study because of their educative objectives. The first one is the National Training Service SENA (Servicio Nacional de Aprendizaje) which offers free training programs focused on vulnerable people and unemployed. The second one are the Regional Centers for Higher Education CERES (Centros Regionales de Educación Superior) that are decentralized educative centers that offer some postsecondary education programs in distant areas; they are supervised academically by one or various IES that are on charge of the design and strategy of these programs.

As mentioned before, to access Postsecondary Education students must present SABER-11 test results. This test is provided by ICFES (Instituto Colombiano para la Evaluación de la Educación), the Colombian Institute for Educational Evaluation which supports the MEN providing information related to the quality of education of the country. SABER-11 test measures the achievement of students who are at senior year (last year of secondary education) in six different areas: Language, Math, Social Sciences, Biology, Chemistry and Physics. Each area is graded over 100 points, and even though there is no pass mark, if the student gets a score from 0 to 30 it is considered low; if the score is between 30.01 and 70 , it is average; and if the score is above 70.01 it is considered high.

\footnotetext{
${ }^{5}$ In spanish: Instituciones de Educación Superior - IES
} 
Because of SABER-11 test design, it grades not only the student's knowledge about a specific subject, but also measures his competences. These competences can be understood as the mental processes and tools that he uses to solve the questions, which reflex somehow the cognitive abilities of the student.

\section{Economic Returns to Postsecondary Education}

Every day young high school graduates decide to invest in postsecondary education programs because they believe that "education pays off". People invest not only between three and five years of their lives, but also, considerable amounts of money that are usually financed by credit (Eckel et al., 2007; Neill, 2008; Carmichael and Finnie, 2008). Their motivation lies on increasing the likelihood of getting a job in the future that would generate revenues enough to recover their high investments.

This logic is supported by several academic studies that have demonstrated the existence of a positive correlation between the education level and the income of an individual throughout his life (Willis and Rosen, 1979; Kane and Rouse, 1995, Card, 1999). Similarly, Cheeseman Day and Newburger (2002) note that American workers who hold a bachelor degree earn through their lifetimes about $77 \%$ higher incomes than those individuals who only graduate from high school. Among recent studies, Carnevale et al. (2012) suggest that postsecondary education is the key to access future economic opportunities since individuals with that level of education compared to those who didn't attend to postsecondary education, have substantially higher incomes over their lifetimes (about $84 \%{ }^{6}$ ).

About Latin America, there is also a positive correlation (Psacharopolous and Chu Ng, 1992, Behrman et al., 2007; Mancorda et al., 2010); nevertheless, the magnitude of the estimated returns is much lower than

\footnotetext{
${ }^{6}$ During his lifetime an individual that holds a bachelor degree can earn incomes $84 \%$ above the income of individuals with a high school diploma
} 
the estimations for developed countries. For example, Contreras et al. (2005) estimated 9\% of higher returns for individuals with postsecondary education in Chile; Morales-Ramos (2011) estimated returns between $8.2 \%$ and $8.4 \%$ higher per additional year of education in Mexico, while Lustig et al. (2012) points out that tertiary education returns are 2 percentage points above the returns to secondary education in Argentina and 4 percentage points in Brazil.

There are also some studies that analyze the economic returns to Postsecondary Education specifically in Colombia. Sanchez \& Nuñez (2012) for example, based on urban household surveys from 1976 to 1998, estimated returns to education through a Mincer equation using a cohort technique. They found that individuals who completed college have the highest returns to education, and that these returns are around $80 \%$ above of those obtained by individuals that only completed high school.

Mora (2003), applied the Hungerford and Solon Test (1987) to an income quantile regression using the National Household Survey for year 2000. The results of the estimation showed that a university degree generates returns between $17.2 \%$ and $27.8 \%$ compared to returns of high school diploma that range between $7.6 \%$ and $17.1 \%$.

Garcia et al. (2009) in order to overcome Mincer equation methodological criticisms estimated the internal rate of return to higher education according to Heckman et al. (2005) methodology. Based on National Household Surveys from 2001 to 2005, they estimated an internal rate of return of education as it where a financial project and compared its potential reward to two different interest rates for Colombia (fixed term interest rate and the natural interest rate). The results show that university is a high return investment and that it's at least $1 \%$ above any of the two interest rates. 
Prada (2006) also found that even though the returns to education from university are the highest compared to secondary and primary education, they are unstable and very sensitive to changes in the economic cycle. Additionally, for individuals that hold a university degree Forero \& Ramirez (2008) identified as the most important determinants for labor income, their age, gender, parents education level, the area of knowledge of the job, if the individual lives in the capital city (Bogotá) and if the IES where the agent obtained the degree is certified.

Even though the precedent studies show that in Colombia there are better economic returns for those graduates that hold a postsecondary degree, there is no study that compare the returns of each postsecondary degree one to another; these studies neither include the effect of the cognitive abilities of the individuals as part of the explanation of those returns. These abilities are an important factor while making the decision about to invest or not in postsecondary education because they reflect the skills an individual has to successfully complete the degree he has chosen.

As Hunter (1986) found, general cognitive ability is positively related to performance in all jobs. This implies that people with higher cognitive abilities are prone to outstand at work and also at education processes. These cognitive abilities are intellectual skills such as understanding, remembering and reasoning that individuals use to solve problems. However, we consider that cognitive skills also reflect somehow the unobservable characteristics (noncognitive abilities) such as motivation, habits, preferences, discipline, persistence, self-esteem, etc. that cannot be directly observed but also affect the individual's decisions.

That is the reason why we aim to estimate the rates of return to postsecondary education in Colombia controlling by individuals' cognitive abilities. They will help us capture the unobserved heterogeneity that 
may cause that people with the same endowments and the same postsecondary education degree might get different economic returns.

\section{Model and Empirical Strategy}

We split our empirical strategy in two different phases. On the first one, we estimated an approximation to the individual's cognitive abilities represented by SABER-11 test results. We consider that, even though cognitive skills captured in SABER-11 test results do not totally represent noncognitive abilities, they somehow reflect them. Besides that, Heckman et al. (2006a) found that even though cognitive skills affect the variance of wages the most, cognitive and noncognitive abilities effects over the variance of wages are very similar.

On the second phase, we estimated the labor market outcomes ${ }^{7}$ for each type of postsecondary degree including the previous estimation of abilities as covariate. We compare basic scenario (Bachelor degree) economic returns with the economic returns of Professional-Technical degree, Technological degree, Specialization degree and Master degree ${ }^{8}$. These estimations were made through matching techniques.

\subsection{Assessing individuals' abilities}

Following Carneiro et al. (2003), Hansen et al. (2004) and Reyes et al. (2013), we used standardized test scores (SABER-11 test) to approximate individuals' abilities. We also kept in mind the assumption proposed initially by Heckman et al. (2006a) that states that at the moment the individual makes a decision about his postsecondary education, his abilities (cognitive and non-cognitive) are fixed and are known by him but not for the researcher.

\footnotetext{
${ }^{7}$ We use the terms "labor market outcomes" and "economic returns" interchangeably.

${ }^{8}$ We didn't include "Doctoral Degree" because of the size of our simple (very small number of doctoral graduates were part of OLE's database)
} 
We used scores of SABER-11 test for the following knowledge areas: language, math, biology, chemistry and physics. Since SABER-11 test is taken at senior year, these abilities are observed before the individual decides which level of postsecondary education to attend. Thus, as mentioned before, they can be considered by the individual as a sign of how well prepared is he for postsecondary education.

Because SABER-11 test results are not comparable across years, we calculated percentiles specific for each year in order to have and indicator of the individual's academic performance by knowledge area. These results were used as covariates while applying matching algorithms allowing us to control individuals' abilities.

\subsection{Labor Market Outcomes}

We analyzed the economic returns of postsecondary education through comparison by setting as basic scenario (Bachelor degree) and comparing it one by one with other three postsecondary degrees.

The empirical strategy applied consisted on estimate the average treatment effect on the treated (ATT) through matching algorithms. By applying this technique we would be able to calculate the economic returns the individual who holds a bachelor degree would have had, had he choose a different postsecondary degree.

In order to have a proper counterfactual to compare the economic returns with, we represented the individual's decision through a logistic regression of the binary category university/other postsecondary degree. Then we match these individuals with other individuals with similar propensities. To estimate this propensity we controlled for different covariates that include 
individual's characteristics, institution characteristics, tuition costs and the individual's abilities (previously estimated) that are summarized in a propensity score.

As identification strategy, matching techniques balance covariate distributions between treated ${ }^{9}$ (other postsecondary degree) and non-treated individuals (bachelor degree). Treatment (T) is assigned independent of potential outcomes $\mathrm{Y}(\mathrm{i})$, where $\mathrm{i}=1$ for other postsecondary degree labor market outcomes and $\mathrm{i}=0$ for bachelor degree labor market outcomes. Therefore, we expect similar average outcomes if both groups receive the same treatment or if none of them do, which can be represented by the following equations:

$$
\begin{aligned}
& \mathrm{E}[\mathrm{Y}(1) \mid \mathrm{T}=1]=\mathrm{E}[\mathrm{Y}(1) \mid \mathrm{T}=0]=\mathrm{E}[\mathrm{Y}(1)] \\
& \mathrm{E}[\mathrm{Y}(0) \mid \mathrm{T}=1]=\mathrm{E}[\mathrm{Y}(0) \mid \mathrm{T}=0]=\mathrm{E}[\mathrm{Y}(0)]
\end{aligned}
$$

These equations show that the average potential outcome for the treatment group under treatment is equal to the average potential outcome of the control group, had it been treated (equation 1), and that the average potential outcome for the treated group, had it not been treated, is equal to the average potential outcome of the control group with no treatment (equation 2).

Based on this, the ATT is estimated using the following equation, where $\mathrm{E}[\mathrm{Y}(0) \mid \mathrm{T}=1]$ represents the counterfactual:

$$
\mathrm{E}[\mathrm{Y}(1)-\mathrm{Y}(0) \mid \mathrm{T}=1]=\mathrm{E}[\mathrm{Y}(01) \mid \mathrm{T}=1]-\mathrm{E}[\mathrm{Y}(0) \mid \mathrm{T}=1]
$$

However, the estimation of the ATT would only be correct if treatment were assigned randomly, thus making the outcomes independent. Unfortunately, this was not the case because we set which

\footnotetext{
${ }^{9}$ We will use traditional "matching" jargon and use the term "treatment group" when referring to the other postsecondary degree we are comparing the economic returns with, and "control group" when referring to the basic scenario (bachelor degree).
} 
individuals to be control and which to be treated. As a consequence, we will use the conditional independence assumption (CIA) that ensures that the distributions of key covariates are balanced across the treatment and control groups.

At this point, we have specified our identification strategy (propensity matching score); however, there are many matching metrics available to achieve our goals. The best matching metric is the one that provides the best balance across our covariates of interest; for this estimations is "nearest neighbor" ${ }^{\prime 10}$ which considers each treated (control) unit and searches for a control (treated) unit with the closest propensity score. We used the variation in this metric that includes replacement, which means that an untreated individual can be used more than once as a match for treated units.

\subsection{Data Description}

One of the advantages of our data is that the information at individual level that we have merged hasn't been use altogether before, such as the SABER 11 test scores, the socio-economic characteristics of the recent graduates, their salaries and the tuition costs of the programs.

Our data base includes information from year 2007 until year 2011 restricted to individuals aged 18 until 35 years old. We used administrative records at individual level from OLE to get the monthly approximation to individuals' wages (we used as proxy for salaries the nominal income used to estimate the individual's contributions for health and pensions). We also used information from the OLE related to the characteristics of the institutions where the individuals obtained their academic degree.

\footnotetext{
${ }^{10}$ We compared estimations using nearest neighbor (NN) with different metrics and NN is the one that provided the best balance.
} 
We integrated this information with individual data from the MEN related to the socioeconomic characteristics of the individuals and their households at the time they took the SABER-11 test and of course the SABER-11 test scores. Finally, also from the MEN, we gathered information about program's annual tuition costs (provided by program and year).

Unfortunately there are data limitations too, such as that OLE information is only available for postsecondary education graduates. This constraint prevents us to compare the economic returns with individuals who drop out postsecondary education, and also with those who decided not to attend postsecondary education at all.

Our sample has 190.111 observations, and after estimating the returns for the whole sample (general estimation) we split it in two different subsamples by origin of the institution (public and private). The private subsample has 106.350 observations and the public subsample has 83.761 observations.

The covariates used in the estimations are: individual's characteristics (age, sex, mother's education, father's education, and number of income contributors in the household), individual's abilities (math, language, biology, chemistry and physics SABER-11 test scores ${ }^{11}$ ), IES characteristics (if the IES has a high quality accreditation, methodology ${ }^{12}$ and tuition costs) and finally, the number of related undergrad programs taken. These covariates were used to estimate the returns using the subsamples public and private; nevertheless, while using the whole sample we included an extra covariate which controls for the origin of the IES.

\footnotetext{
${ }^{11}$ Recalculated the way me mentioned earlier (section 4.1)

12 On-line courses (a distancia) or if the student has to attend classes physically (presencial)
} 


\section{Estimation and Results}

As earlier mentioned, our empirical strategy specified in Section 4 was first applied to the full sample (general). Table 2, shows significative estimations (t-stat) while comparing the returns obtained as a result of holding a bachelor degree (basic scenario) with four different postsecondary degree labor market outcomes. It is worth to mention that all the estimations registered over $99 \%$ of common support (except by Master degree which registered $92 \%$ of common support) and the key covariates were balanced across the treatment and control groups (Annex 1).

As can been seen, the economic returns of an individual that holds a bachelor degree had he chosen a professional-technical program, would have been 9,24\% higher compared with the average bachelor degree monthly wage. The reason for this might be that professional-technical programs are focused on specific job and career needs, which means that the individual developed a certain degree of proficiency on specific tasks that are compensated through a higher salary.

On the other hand, had the individual chosen a technological program, his returns would have been around $7,17 \%$ lower than the average bachelor degree monthly wage. Usually, technical programs have a 1 or 2 year duration (compared with the 4 or 5 year duration of bachelor degree) and the tuition costs are lower than those of bachelor degree.

Finally, to improve bachelor degree with a specialization or with a master course increases the economic returns by $61,6 \%$ and $83,9 \%$ respectively. It can be noted that gaining expertise on specific knowledge areas brings higher economic returns to the individuals. 
While analyzing the data by the institution origin it can be seen that results are slightly different. Table 3 shows the results for those degrees gotten at private institutions ${ }^{13}$. Under this setup it can be seen that even though the magnitudes of the variations in the economic returns change, the direction of the effects concords with the results obtained with the full sample (general).

While analyzing the economic returns that an individual that holds a bachelor degree from a private institution, would have had, had he chosen a professional-technical degree also from a private institution, it can be seen an increase of $72,86 \%$ on his returns (much higher than on a general scenario). Had the individual chosen a technological degree, his wage would have been $3,41 \%$ lower.

Finally, had the individual chosen a specialization, his economic returns would have been $35,46 \%$ higher, and had he hold a Master degree, his returns would have been $49,98 \%$ higher. While comparing these results with those obtained with the full sample, it can be inferred that private institutions report higher economic returns as more specific abilities are developed (professional-technical).

Table 4 exhibits the results for the public institutions subsample estimations ${ }^{14}$; they show that had an individual that hold a bachelor degree from a public institution had chosen a professional-technical degree, would have gotten a $29,37 \%$ lower wage. Similarly, had he chosen a technological program, his returns would have been $14,28 \%$ lower.

\footnotetext{
${ }^{13}$ All the estimations for the private subsample registered over $95 \%$ of common support (except by Master Degree which registered $94 \%$ of common support) and the key covariates were balanced across the treatment and control groups.

${ }^{14}$ All the estimations for the private subsample registered over $98 \%$ of common support (except by Master Degree which registered $87 \%$ of common support) and the key covariates were balanced across the treatment and control groups.
} 
On the other hand, had the individual that holds a bachelor degree, had chosen to attend a specialization, his economic returns would have been $70,66 \%$ higher. Similarly, had the individual had chosen to attend a master's program; his wage would have been more than twice the wage he perceives as bachelor graduate. This shows that only specialization and master programs at public institutions would have reported higher economic returns as alternative scenarios.

\section{Conclusions}

By integrating information at individual level that includes socioeconomic background, labor market outcomes, IES characteristics, tuition costs and especially individuals' cognitive abilities; we were able to bring novel empirical evidence about the economic returns of postsecondary education in Colombia. These estimations are much more precise because they consider the presence of heterogeneity by including individuals' abilities ${ }^{15}$; this makes the estimation of parallel scenarios (comparing postsecondary education degrees' labor market outcomes) much more useful for public policy than previous research.

Our estimations are based on comparing the economic returns across postsecondary education academic degrees using as basic scenario, the returns perceived while holding a bachelor degree. The estimations show in a broad sense that getting a master's degree or a specialization degree will always be better than a bachelor's degree. For private institutions, a master's degree would increase individual's wage in $41 \%$ and for public ones the increase would be around $114 \%$. For specializations, in private institutions, this degree increases wages in around 35,56\%, and in public institutions in 70,66\%. This also gives a hint about higher wages if the academic degree (graduate degree) was obtained from public institutions.

\footnotetext{
${ }^{15}$ As mentioned before, we consider that standardized test scores such as SABER-11 reflect not only individuals' cognitive abilities, but also somehow non-cognitive ones.
} 
When comparing the results with professional-technical degrees, it is interesting to notice that the results are different depending on the origin of the institution. If the professional-technical degree was obtained from a private institution, it shows wages $72,86 \%$ higher, but, if this degree was obtained from a public institution the wages would be $29,37 \%$ lower. About technological degree, our results show lower wages than the bachelor degree in all scenarios. If the institution was private, the economic returns would be $3,41 \%$ lower and if the institution was public, the wages would be $14,28 \%$ lower.

These results open a question about how much does the labor market valuates the origin of the institution and if the quality of the degrees is associated with it; this because, our estimations always show lower wages for all postsecondary degrees that were obtained on a public institution.

In addition, these results permit us to identify which academic degrees of postsecondary education are the ones that bring higher economic returns to individuals. For private institutions professional-technical degrees are the ones that bring higher economic returns, and for public institutions, master degrees. The implications of these results can be used while prioritizing public expenditure on postsecondary education.

Through these results we can also determine which postsecondary education degrees require to be analyzed more in order to identify the reasons of their low economic returns such as the technological degrees (from both, public and private institutions) and the professional-technical degree from public institutions. 


\section{REFERENCES}

Behrman, J., Birdsall, N. and Szekely, M. (2007). Economic Policy and Wage Differentials in Latin America. Economic Development and Cultural Change, 56.

Cameron, S. y Heckman, J. (1998). Life Cycle Schooling and Dynamic Selection Bias: Models and Evidence for Five Cohorts of American Males. Journal of Political Economy 106(2), 262-333.

Card, D. (1999) The Causal Effect of Education on Earnings, en Handbook of Labor Economics, editado por Ashenfelter, O y Card, D., vol. 5, pp. 1801-1863. North-Holland, New York.

Card, D. (2001). Estimating the Return to Schooling: Progress on Some Persistent Econometric Problems. Econometrica 69(5), 1127-1160.

Carmichael, L. and Finnie, R. (2008) Grants for Students: Equal Access to Post-Secondary Education Requires More Than a Student Loan Program. MESA Project Research Paper. Educational Policy Institute - Queen's University School of Policy Studies, Canada.

Carneiro, P., and Heckman, J. (2002). The Evidence on Credit Constraints in Post- Secondary Schooling. Economic Journal 112(482), 705-734.

Carnevale, A., Rose, S. and Cheah, B (2012) The College Payoff: Education, Ocupations, Lifetime Earnings. The Georgetown University Center on Education and the Workforce.

Cheeseman Day and Newburger (2002). The Big Payoff: Educational Attainment and Synthetic Estimates of Work-Life Earnings. Special Studies, Census Bureau. Washington, D.C.

Contreras, D., Melo, E. and Ojeda, S. (2005). Estimando el Retorno a la Educación o a los no Observables?: Evidencia de Datos de Panel. Estudios de Economía, 32(2), 187-199.

Eckel, C. Johnson, C., Montmarquette, C. and Rojas, C. (2007). Debt Aversion and the Demand for Loans for Post-Secondary Education. Public Finance Review 35, 233-262.

Dolton, P. and Vignoles, A. (2000). The incidence and effects of overeducation in the U.K. graduate labour market. Economics of Education Review 19, 179-198. 
Garcia-Suaza, A., Guataquí, J., Guerra, J. and Maldonado, D. (2009) Beyond the Mincer Equation: The internal Rate of Return to Higher Education in Colombia. Serie Documentos de Trabajo 68, Universidad del Rosario

Hansen, K., Heckman, J. and Mullen, K. (2004). The Effect of Schooling and Ability on Achievement Test Scores. Journal of Econometrics, 121(1-2), 39-98.

Heckman, J., Lochner, L. and Todss, P. (2005). Earnings Functions, Rates of Return, and Treatment Effects: The Mincer Equation and Beyond. NBER Working Paper Series 11544.

Heckman, J., Stixrud, J., and Urzua, S. (2006). The Effects of Cognitive and Noncognitive Abilities on Labor Market Outcomes and Social Behavior. Journal of Labor Economics, 24(3), 411-482

Hungerford, T. and Solon, G. (1987). Sheepskin Effects in the Returns to Education. Review of Economics and Statistics 69(1), 175-177

Hunter, J.E. (1986). Cognitive ability, cognitive aptitudes, job knowledge, and job performance. Journal of Vocational Behavior 29, 340-362

Kane, T. y Rouse, C. (1995). Labor-Market Returns to Two- and Four-Year College. American Economic Review 85(3), 600-614.

Keane, M. y Wolpin, K. (1997). The Career Decisions of Young Men. Journal of Political Economy 105(3), 473-522.

Lustig, N., Lopez-Calva, L. and Ortiz-Juarez, E. (2012). Declining Inequality in Latin America in the 2000s: The Cases of Argentina, Brazil and Mexico. Policy Research Working Paper 6248. The World Bank

Manacorda, M., Sanchez-Parama, C., and Schady, N (2010. Change in the returns to education in Latin America: The role of demand and supply of skills. Industrial and Labor Relations 63(2).

Mora, J. (2003) Sheepskin effects and screening in Colombia. Colombian Economic Journal 1(1), 95-108

Morales-Ramos, E. (2011). Rendimientos de la Educación en México. Banco de Mexico Working Papers 2011(07). 
Maxwell, L. (1979). Some Evidence on Negative Returnes to Graduate Eduaction. Economic Inquiry 8(2), 186-189

Neill, C. (2008) The Effect of Student Loan Limits on University Enrolments. Candaian Labour Market and Skills Researcher Network Working Papers (4).

Psacharopolous, G. and Chu Ng, Y. (1992) Earnings and Education in Latin America, Assesing Assessing Priorities for Schooling Investments. The World Bank Working Papers. WPS 1056

Psacharopolous, G. and Chu Ng, Y. (1992) Earnings and Education in Latin America, Assesing Assessing Priorities for Schooling Investments. The World Bank Working Papers. WPS 1056

Rau, T. (2013). Modeling structural equations with endogenous regressors and heterogeneity through derivative constraints. Quantitative Econometrics 4, 125-148.

Reyes, L., Rodríguez, J., Urzúa, S. (2013) Heterogeneous Economic Returns to Postsecondary Degrees: Evidence From Chile. NBER Working Papers Series. Working Paper 18817.

Sanchez, F. and Nuñez, J. (2002). A Dynamic Analysis of Household Decision-Making in Urban Colombia, 1976-1998: Changes in Household Structure, Human Capital and its Returns, and Female Labor Force Participation. Research Network Working papers (449). Interamerican Bank of Development.

Willis, R. and Rosen, S. (1979). Education and Self-Selection. Journal of Political Economy 87( 5), S7S36 


\section{TABLES}

Table 1: IES Academic Classification

\begin{tabular}{|c|c|c|}
\hline $\begin{array}{l}\text { Academic Classification of } \\
\text { IES }\end{array}$ & $\begin{array}{l}\text { Undergraduate } \\
\text { Programs }\end{array}$ & $\begin{array}{l}\text { Graduate } \\
\text { Programs }\end{array}$ \\
\hline $\begin{array}{l}\text { Professional-Technical } \\
\text { Institutions } \\
\text { (programs for a particular } \\
\text { career or job) }\end{array}$ & - Professional Technical Programs & - Professional Technical Specializations \\
\hline Technological Institutions (1) & $\begin{array}{l}\text { - Professional Technical Programs } \\
\text {-Technological Programs }\end{array}$ & $\begin{array}{l}\text { - Professional Technical Specializations } \\
\text {-Technological Specializations }\end{array}$ \\
\hline $\begin{array}{l}\text { University Institutions } \\
\text { (all undergraduate programs } \\
\text { and graduate programs up to } \\
\text { specializations) }\end{array}$ & $\begin{array}{l}\text { - Professional Technical Programs } \\
\text {-Technological Programs } \\
\text {-Professional Programs }\end{array}$ & $\begin{array}{l}\text { - Professional Technical Specializations } \\
\text {-Technological Specializations } \\
\text {-Professional Specializations }\end{array}$ \\
\hline $\begin{array}{l}\text { Universities } \\
\text { (all undergraduate and all } \\
\text { graduate programs) }\end{array}$ & $\begin{array}{l}\text { - Professional Technical Programs } \\
\text {-Technological Programs } \\
\text {-Professional Programs }\end{array}$ & $\begin{array}{l}\text { - Professional Technical Specializations } \\
\text {-Technological Specializations } \\
\text {-Professional Specializations } \\
\text {-Master Degree Programs } \\
\text {-Doctoral Degree Programs }\end{array}$ \\
\hline
\end{tabular}

Source: Authors with information from the MEN

Note: Each type of IES by academic classification is also divided by origin (public or private)

1. Technological institutions are focused on different knowledge areas than professional-technical institutions. The latter are focused on upgrading specific career or job knowledge.

\section{TABLE 2 : General}

Control Group: Bachelor Degree

\begin{tabular}{|c|c|c|c|c|c|c|}
\hline $\begin{array}{l}\text { Academic Degree } \\
\text { (treatment) }\end{array}$ & Treated & Controls & Difference & S.E. & t-stat & $\begin{array}{l}\text { Variation } \\
\text { respect to } \\
\text { the mean }\end{array}$ \\
\hline Professional-Technical & $854.494,36$ & $772.243,67$ & $82.250,68$ & $35.707,99$ & 2,30 & $9,24 \%$ \\
\hline Technological & $695.850,18$ & $759.643,58$ & $-63.793,40$ & $13.274,04$ & $-4,81$ & $-7,17 \%$ \\
\hline Specialization & $1.517 .165,61$ & $968.857,14$ & $548.308,47$ & $40.131,27$ & 13,66 & $61,60 \%$ \\
\hline Master & $1.814 .679,02$ & $1.067 .787,56$ & $746.891,47$ & $155.487,64$ & 4,80 & $83,90 \%$ \\
\hline
\end{tabular}




\section{Table 3: Private}

Control Group: Bachelor Degree

\begin{tabular}{lrrrrrc}
\hline $\begin{array}{l}\text { Academic Degree } \\
\text { (treatment) }\end{array}$ & Treated & Controls & Difference & S.E. & t-stat & $\begin{array}{c}\text { Variation } \\
\text { respect to } \\
\text { the mean }\end{array}$ \\
Professional-Technical & $1.340 .089,34$ & $643.879,90$ & $696.209,44$ & $102.151,92$ & 6,82 & $72,86 \%$ \\
Technological & $676.397,54$ & $709.002,43$ & $-32.604,89$ & $16.723,48$ & $-1,96$ & $-3,41 \%$ \\
Specialization & 1170973,87 & 832.128 & 338.846 & 64.475 & 5,26 & $35,46 \%$ \\
Master & 1408647,08 & 1017058,54 & 391.589 & 185.256 & 2,11 & $40,98 \%$
\end{tabular}

Table 4: Public

Control Group: Bachelor Degree

\begin{tabular}{lcccccc}
\hline $\begin{array}{l}\text { Academic Degree } \\
\text { (treatment) }\end{array}$ & Treated & Controls & Difference & S.E. & t-stat & $\begin{array}{c}\text { Variation } \\
\text { respect to } \\
\text { the mean }\end{array}$ \\
Professional-Technical & $640.891,82$ & $874.420,06$ & $-233.528,24$ & $28.643,51$ & $-8,15$ & $-29,37 \%$ \\
Technological & $726.809,07$ & $840.365,25$ & $-113.556,18$ & $22.019,38$ & $-5,16$ & $-14,28 \%$ \\
Specialization & $1.607 .368,22$ & $1.045 .586,09$ & $561.782,13$ & $50.126,07$ & 11,21 & $70,66 \%$ \\
Master & $2.026 .075,65$ & $1.120 .506,97$ & $905.568,68$ & $204.213,23$ & 4,43 & $113,90 \%$
\end{tabular}




\section{ANNEX 1 : BALANCE ACROSS COVARIATES}

In order to verify if the covariates were balanced across treatment and control groups, we used the following criteria for balance:

\begin{tabular}{|c|c|c|c|}
\hline Unbalance level 3 (U3) & Unbalance level 2 (U2) & Unbalance level 1 (U1) & Balanced (*) \\
\hline yenn & $1,96=<\mathrm{t}<2,6$ & $1,64=<\mathrm{t}<1,96$ & \multirow{2}{*}{$\mathrm{t}<1,64$} \\
\hline Serious & Moderate & Small & \\
\hline
\end{tabular}

Even though most of our covariates are balanced (covariates' means do not significantly different across treatment and control groups) we identified some covariates with a U3 level of unbalance. In that case, we applied the rule of a thumb that states that a percentage of bias of less than $10 \%$ is acceptable.

GENERAL SAMPLE:

\begin{tabular}{|c|c|c|c|c|c|c|c|c|c|c|}
\hline & & chnical - Pr & ofesional & & & & Technolo & gical & & \\
\hline & Treated & Control & \%bias & t-test & & Treated & Control & \%bias & $\begin{array}{l}\text { t- } \\
\text { test }\end{array}$ & \\
\hline age & 24,76 & 24,83 & $-4,7$ & 1,61 & $*$ & 24,68 & 24,70 & $-1,6$ & 1,33 & $*$ \\
\hline sex & 0,55 & 0,54 & 2,1 & $-0,12$ & $*$ & 0,49 & 0,49 & $-0,2$ & $-1,55$ & $*$ \\
\hline edu_mom & 3,20 & 3,19 & 0,7 & 1,00 & $*$ & 3,17 & 3,14 & 2,0 & 1,09 & $*$ \\
\hline edu_dad & 3,20 & 3,21 & $-0,2$ & 1,13 & $*$ & 3,14 & 3,12 & 1,3 & 1,03 & $*$ \\
\hline matricula & 5.300 .000 & 5.300 .000 & $-1,0$ & 1,34 & $*$ & 5.000 .000 & 5.000 .000 & $-3,3$ & 0,73 & $*$ \\
\hline meto & 1,04 & 1,03 & 3,8 & 1,52 & $*$ & 1,12 & 1,11 & 4,3 & $-1,76$ & U1 \\
\hline acred & 0,00 & 0,00 & 0,0 & 0,05 & $*$ & 0,12 & 0,10 & 4,5 & 1,90 & U1 \\
\hline pre_afines & 0,02 & 0,01 & 2,3 & 1,67 & & 0,040 & 0,038 & 0,6 & $-1,16$ & $*$ \\
\hline aportantes & 1,58 & 1,60 & $-2,8$ & $-1,04$ & $*$ & 1,54 & 1,55 & $-1,3$ & 1,70 & U1 \\
\hline math & 37,47 & 36,77 & 2,5 & 1,73 & U1 & 38,58 & 38,42 & 0,6 & 1,10 & $*$ \\
\hline language & 31,98 & 31,96 & 0,1 & 1,28 & $*$ & 34,94 & 34,66 & 1,0 & 1,43 & $*$ \\
\hline biology & 32,59 & 32,73 & $-0,5$ & 1,36 & $*$ & 35,46 & 35,19 & 1,0 & 1,56 & $*$ \\
\hline chemistry & 32,27 & 32,25 & 0,1 & 1,65 & U1 & 35,80 & 35,55 & 0,9 & 1,93 & U1 \\
\hline physics & 36,63 & 36,53 & 0,4 & 1,06 & $*$ & 39,67 & 39,83 & $-0,6$ & 1,35 & $*$ \\
\hline ies_orig & 1,698 & 1,705 & $-1,3$ & $-1,47$ & $*$ & 1,39 & 1,41 & $-4,7$ & 1,88 & U1 \\
\hline
\end{tabular}




\begin{tabular}{|c|c|c|c|c|c|c|c|c|c|c|}
\hline \multirow[b]{3}{*}{ age } & \multicolumn{5}{|c|}{ Specialization } & \multicolumn{5}{|c|}{ Master } \\
\hline & Treated & Control & $\%$ bias & t-test & & Treated & Control & $\%$ bias & t-test & \\
\hline & 25,18 & 25,14 & 3,2 & $-1,64$ & U1 & 25,20 & 25,27 & $-5,1$ & $-1,08$ & $*$ \\
\hline sex & 0,37 & 0,37 & $-0,1$ & 0,82 & $*$ & 0,53 & 0,48 & 10,7 & 1,9 & $\mathrm{U} 1$ \\
\hline edu_mom & 4,55 & 4,38 & 10 & $-1,1$ & $*$ & 4,89 & 4,57 & 1,8 & $-1,58$ & $*$ \\
\hline edu_dad & 4,56 & 4,37 & 11 & $-1,31$ & $*$ & 4,97 & 4,72 & 14 & $-1,36$ & $*$ \\
\hline matricula & 6.600 .000 & 6.300 .000 & 9,5 & $-1,67$ & U1 & 6.400 .000 & 6.200 .000 & 8,6 & $-1,05$ & * \\
\hline meto & 1,02 & 1,03 & $-4,8$ & 2,31 & $\mathrm{U} 2$ & 1,01 & 1,01 & 0 & 0,94 & * \\
\hline acred & 0,53 & 0,41 & 5,4 & $-1,63$ & $*$ & 0,86 & 0,70 & 3,8 & $-1,47$ & $*$ \\
\hline pre_afines & 0,45 & 0,54 & $-2,6$ & $-2,70$ & U3 & 0,40 & 0,60 & $-6,7$ & $-2,11$ & $\mathrm{U} 2$ \\
\hline aportantes & 1,58 & 1,58 & 0,5 & 1,02 & $*$ & 1,61 & 1,61 & 0 & 0,6 & $*$ \\
\hline math & 51,49 & 49,64 & 6,3 & $-1,94$ & U1 & 66,20 & 64,01 & 7,3 & $-1,72$ & $\mathrm{U} 1$ \\
\hline language & 53,74 & 50,35 & 8,7 & $-1,49$ & $*$ & 65,32 & 62,61 & 6,2 & $-0,81$ & $*$ \\
\hline biology & 52,63 & 49,95 & 9,2 & $-1,71$ & $\mathrm{U} 1$ & 65,41 & 64,53 & 8,3 & $-1,41$ & $*$ \\
\hline chemistry & 54,21 & 51,51 & 9,3 & $-1,56$ & $*$ & 70,15 & 66,68 & 7,5 & $-1,28$ & $*$ \\
\hline physics & 50,52 & 48,57 & 6,7 & $-0,47$ & $*$ & 65,54 & 64,80 & 2,5 & $-1,29$ & $*$ \\
\hline ies_orig & 1,79 & 1,78 & 1,7 & $-1,65$ & U1 & 1,63 & 1,64 & $-3,9$ & $-4,42$ & $\mathbf{U 3}$ \\
\hline
\end{tabular}

\section{PRIVATE INSTITUTIONS SUBSAMPLE:}

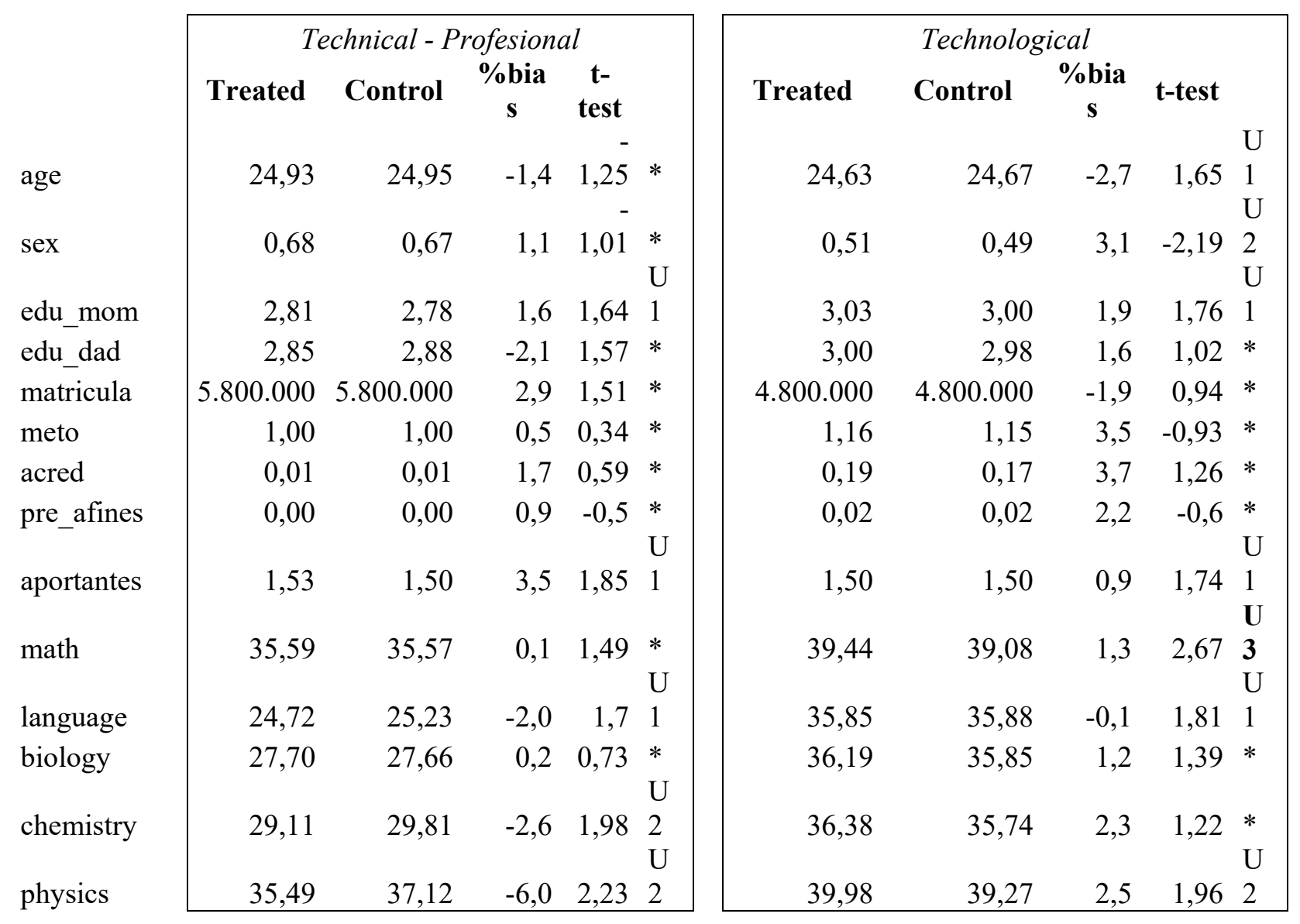




\begin{tabular}{l|rrrrl} 
age & 25,04 & 25,10 & $-3,8$ & $-0,97$ & $*$ \\
sex & 0,43 & 0,48 & $-9,7$ & $-2,2$ & U2 \\
edu_mom & 3,96 & 3,99 & $-1,6$ & $-1,29$ & $*$ \\
edu_dad & 3,94 & 3,95 & $-0,7$ & $-1,26$ & $*$ \\
matricula & 6.500 .000 & 6.500 .000 & 2,4 & $-1,52$ & $*$ \\
meto & 1,03 & 1,04 & $-5,7$ & 1,22 & $*$ \\
acred & 0,46 & 0,37 & 16,7 & 0,14 & $*$ \\
pre_afines & 0,37 & 0,37 & $-0,9$ & $-1,57$ & $*$ \\
aportantes & 1,55 & 1,56 & $-1,3$ & $-0,43$ & $*$ \\
math & 51,81 & 48,35 & 7,6 & 0,41 & $*$ \\
language & 52,80 & 50,90 & 6,6 & $-2,19$ & U2 \\
biology & 52,74 & 51,25 & 5,1 & $-3,3$ & U3 \\
chemistry & 53,51 & 50,82 & 9,1 & 0,18 & $*$ \\
physics & 50,11 & 44,41 & 11,6 & 4,73 & U3 \\
\hline
\end{tabular}

\begin{tabular}{|rrrrl|}
\hline \multicolumn{6}{c|}{ Master } \\
Treated & Control & \%bias & t-test & \\
25,01 & 25,28 & $-9,5$ & $-2,31$ & U2 \\
0,49 & 0,50 & $-2,6$ & $-1,23$ & $*$ \\
3,72 & 3,80 & $-4,4$ & $-2,48$ & U2 \\
3,70 & 3,87 & $-9,8$ & $-4,31$ & U3 \\
6.200 .000 & 6.000 .000 & 14,7 & $-1,17$ & $*$ \\
1,00 & 1,00 & --- & --- & --- \\
0,78 & 0,75 & 5,8 & $-1,92$ & U1 \\
0,34 & 0,36 & $-3,7$ & $-1,09$ & $*$ \\
1,57 & 1,61 & $-5,9$ & $-1,05$ & $*$ \\
58,40 & 63,50 & $-6,9$ & $-1,69$ & U1 \\
50,86 & 56,93 & $-7,0$ & $-1,65$ & U1 \\
52,71 & 53,71 & $-3,2$ & $-0,7$ & $*$ \\
57,05 & 57,70 & $-2,1$ & $-1,72$ & U1 \\
53,79 & 52,76 & 3,2 & $-2,29$ & U2 \\
\hline
\end{tabular}

PUBLIC INSTITUTIONS SUBSAMPLE:

\begin{tabular}{|c|c|c|c|c|c|c|c|c|c|c|}
\hline & & chnical - Pr & rofesiona & & & & Technolo & gical & & \\
\hline & Treated & Control & \%bias & $\begin{array}{c}\text { t- } \\
\text { test }\end{array}$ & & Treated & Control & \%bias & $\begin{array}{c}\text { t- } \\
\text { test }\end{array}$ & \\
\hline age & 24,68 & 24,73 & $-2,70$ & 1,55 & $*$ & 24,76 & 24,74 & 1,50 & 1,51 & $*$ \\
\hline sex & 0,49 & 0,49 & $-0,50$ & $-1,02$ & $*$ & 0,46 & 0,45 & 2,70 & $-1,58$ & $*$ \\
\hline edu_mom & 3,37 & 3,37 & 0,10 & 0,07 & $*$ & 3,38 & 3,35 & 2,00 & 1,31 & $*$ \\
\hline edu_dad & 3,36 & 3,36 & 0,20 & 0,09 & $*$ & 3,37 & 3,33 & 2,10 & 1,53 & $*$ \\
\hline matricula & 5.100 .000 & 5.100 .000 & $-2,30$ & 1,74 & U1 & 5.300 .000 & 5.400 .000 & $-2,80$ & 1,02 & $*$ \\
\hline meto & 1,05 & 1,04 & 5,30 & $-1,65$ & $\mathrm{U} 1$ & 1,04 & 1,04 & 3,00 & 1,93 & U1 \\
\hline acred & 0,00 & 0,00 & --- & --- & --- & 0,01 & 0,01 & $-0,10$ & 2,06 & $\mathrm{U} 2$ \\
\hline pre_afines & 0,02 & 0,02 & $-0,20$ & 1,48 & $*$ & 0,07 & 0,06 & 3,90 & 1,13 & $*$ \\
\hline aportantes & 1,60 & 1,57 & 3,40 & 0,45 & $*$ & 1,59 & 1,59 & 0,50 & 0,36 & $*$ \\
\hline math & 38,27 & 37,87 & 1,50 & 1,53 & $*$ & 37,21 & 37,21 & 0,00 & 1,38 & $*$ \\
\hline language & 35,12 & 35,81 & $-2,60$ & 1,68 & U1 & 33,49 & 33,48 & 0,00 & 1,86 & U1 \\
\hline biology & 34,71 & 34,62 & 0,30 & 1,39 & $*$ & 34,29 & 33,82 & 1,80 & 1,72 & U1 \\
\hline chemistry & 33,65 & 33,10 & 2,10 & 1,22 & $*$ & 34,87 & 35,02 & $-0,60$ & 1,89 & $\mathrm{U} 1$ \\
\hline physics & 37,14 & 36,68 & 1,70 & 1,93 & U1 & 39,17 & 38,29 & 3,20 & 1,47 & $*$ \\
\hline
\end{tabular}




\begin{tabular}{|c|c|c|c|c|c|c|c|c|c|c|}
\hline & & Specializ & ation & & & & Mast & & & \\
\hline & Treated & Control & \%bias & $\begin{array}{c}\text { t- } \\
\text { test }\end{array}$ & & Treated & Control & $\%$ bias & t-test & \\
\hline age & 25,19 & 25,21 & $-1,00$ & 1,76 & U1 & 25,32 & 25,38 & $-4,60$ & $-1,35$ & $*$ \\
\hline sex & 0,36 & 0,35 & 1,50 & 1,08 & $*$ & 0,55 & 0,50 & 9,80 & $-1,55$ & $*$ \\
\hline edu_mom & 4,69 & 4,49 & 1,70 & 1,96 & $\mathrm{U} 2$ & 5,54 & 5,05 & 3,30 & $-0,90$ & $*$ \\
\hline edu_dad & 4,71 & 4,48 & 3,70 & 1,46 & $*$ & 5,69 & 5,16 & 9,30 & $-1,29$ & $*$ \\
\hline matricula & 6.600 .000 & 6.300 .000 & 6,90 & $2,17^{-}$ & $\mathrm{U} 2$ & 6.400 .000 & 6.600 .000 & $-10,90$ & $-2,10$ & U2 \\
\hline meto & 1,02 & 1,03 & $-2,20$ & $\begin{array}{r}- \\
- \\
-\end{array}$ & U3 & 1,02 & 1,00 & 3,80 & $\begin{array}{r}1,30 \\
-\end{array}$ & $*$ \\
\hline acred & 0,54 & 0,42 & 5,30 & 1,42 & $*$ & 0,90 & 0,77 & 9,20 & 11,49 & U3 \\
\hline pre_afines & 0,46 & 0,56 & $-7,10$ & 1,65 & U1 & 0,40 & 0,62 & $-8,70$ & $-2,39$ & U2 \\
\hline aportantes & 1,59 & 1,56 & 5,20 & 1,55 & $*$ & 1,64 & 1,57 & 10,40 & 0,68 & $*$ \\
\hline math & 51,29 & 50,40 & 3,00 & $-1,8$ & U1 & 70,16 & 61,10 & 10,70 & $-1,76$ & U1 \\
\hline language & 53,67 & 51,14 & 8,70 & $-4,1$ & $\mathbf{U 3}$ & 73,06 & 68,09 & 8,10 & $-1,31$ & $*$ \\
\hline biology & 52,54 & 50,71 & 6,30 & 1,57 & $*$ & 71,85 & 67,69 & 5,40 & $-1,36$ & $*$ \\
\hline chemistry & 54,09 & 51,45 & 9,20 & 2,16 & $\mathrm{U} 2$ & 76,49 & 74,33 & 7,50 & $-1,92$ & U1 \\
\hline physics & 50,51 & 48,46 & 7,10 & 1,14 & $*$ & 71,57 & 67,45 & 8,70 & $-1,59$ & $*$ \\
\hline
\end{tabular}

